Kenji Miura

DOI: 10.33896/PorJ.2021.2.6

(Uniwersytet Warszawski, e-mail: k.miura@uw.edu.pl)

ORCID: 0000-0002-7931-6969

\title{
ADAPTACJA FONETYCZNA I GRAFEMICZNA NAZWISK I IMION POLSKICH WE WSPÓŁCZESNYM JĘZYKU JAPOŃSKIM
}

Zapożyczanie nazwisk polskich w japońskich tekstach medialnych jest najbardziej typowa - a obecnie zarazem najczęstsza - forma bezpośredniego kontaktu polszczyzny i japońszczyzny. Ten pierwszy język odgrywa w takich kontaktach rolę języka źródłowego, natomiast drugi staje się językiem "goszczącym” przejmowany antroponim polski. To "goszczenie" przy tym może mieć charakter chwilowy, doraźny, kiedy w jakimś doniesieniu prasowym czy telewizyjnym jest mowa o osobie noszaceej polskie nazwisko i imię, lub też charakter długotrwały, kiedy nosiciel nazwiska jest dobrze znaną wielu Japończykom postacia, zasłużona w jakiejś - przyciagającej uwagę społeczna - dziedzinie aktywności.

Polska od lat 80. ubiegłego stulecia często gościła na łamach gazet japońskich, gdyż nurt walki o demokrację na wschodzie Europy - uosabiany przez Niezależny Samorządny Związek Zawodowy „Solidarnośc” pod przywództwem Lecha Wałęsy - był wówczas prezentowany w mediach całego świata zachodniego. Nie dziwi zatem fakt, że nazwisko przewodniczącego związku w japońskiej adaptacji brzmiące Waresa [waresa] słyszał niemal każdy mieszkaniec Japonii, a mechanizm tej adaptacji zostanie tu omówiony nieco później.

Takich postaci, wywodzących się z Polski, których nazwiska bądź imiona utrwaliły się na dobre w pamięci co najmniej kilku pokoleń Japończyków, jest niezbyt wiele. W dodatku stopień i zakres ich znajomości zależy przede wszystkim od erudycji danego użytkownika japońszczyzny, jego zainteresowań jakąś określoną dziedzina życia społecznego bądź też od tego, czy utrzymuje on bliższe kontakty z Polska jako krajem i jego tradycją kulturalna.

Możemy zatem zastanowić się nad wyborem przykładów nazwisk i imion reprezentujących tę właśnie kategorię osób sławnych oraz znanych w Japonii. Pierwsza taka postacia byłby niewatpliwie Fryderyk Chopin, którego muzyka jest od ponad stulecia znana szeroko w naszym kraju. Jeżeli chodzi jednak o pojedynczy przypadek językowego kontaktu polsko-japońskiego, odnoszącego się do zapożyczenia tego nazwiska, to możemy tu zaobserwo- 
wać kilka cech nietypowych. Po pierwsze, w języku japońskim kompozytor znany jest pod, zjaponizowaną wprawdzie, ale wywodzaccą się z języka francuskiego postacia nazwiska - brzmiąca Furederikku Shopan - w sylabicznym piśmie katakana zapisywana jako フレデリック・ショパン. Trzeba jeszcze przypomnieć czytelnikom polskim, że w języku japońskim wszystkie zapożyczenia $z$ języków obcych, przejmowane fonetycznie bądź za pośrednictwem pisma fonograficznego, wprowadzane sa do tekstu właśnie w zapisie katakana, która sygnalizuje obcy, zewnętrzny charakter takiego przejętego $z$ zewnattrz słowa. Jest to więc wyraźny sygnał wyodrębniający obce nazwisko i imię spośród pozostałych wyrazów w tekście. ${ }^{1}$ Wracając jednak do formy Furederikku Shopan, musimy zauważyć, że w języku polskim używana jest powszechnie i zapewne od samego początku - kiedy nazwisko kompozytora stało się sławne w Warszawie, Wiedniu, Paryżu i w całej Europie - spolonizowana postać tego nazwiska i imienia, zapisywana Fryderyk Chopin i wymawiana przez wszystkich jako Szopen. ${ }^{2}$ Widać więc, że w tym wypadku nie był to kontakt językowy polsko-japoński, ale francusko-japoński, być może odbywający się za pośrednictwem jakiegoś innego języka europejskiego, niemieckiego bądź angielskiego, w którym również to nazwisko $\mathrm{i}$ imię wymawiane jest $z$ francuska.

Drugim przypadkiem, analogicznym jeśli chodzi o formę kontaktu, może być nazwisko Marii Curie-Skłodowskiej, która wszystkim Japończykom znana jest jako Kyuri-fujin キュリ一夫人, co jest skalkowana postacia francuskiego określenia Madame Curie. Gdyby jakiś użytkownik japońszczyzny usłyszał pełną formę imienia i nazwiska uczonej, używana powszechnie w Polsce w celu zaakcentowania jej rzeczywistego rodowodu i upowszechniona w postaci Maria Sukuwodofusuka-Kyurī マリア・スクウォドフスカニキュリー, to miałby sporo kłopotów $z$ właściwa identyfikacja osoby. Taka postać widnieje, co prawda, w japońskich encyklopediach i dokładniejszych biografiach, ale nie jest ona używana w sytuacjach codziennych, gdyż jako popularna bohaterka masowej wyobraźni w Japonii uczona ta pozostaje jedynie „Panią Curie”. W języku polskim zreszta faktycznie używana postać jej nazwiska ma szyk odwrócony, z nazwiskiem rodowym na drugim miejscu: Maria Curie-Skłodowska. W takim brzmieniu występuje słynna Kyurï-fujin jako patronka państwowego uniwersytetu polskiego mieszczącego się w Lublinie.

W tym wypadku jednak, przynajmniej w oficjalnej wersji jej nazwiska, dochodzi do kontaktu polsko-japońskiego, gdyż forma Sukuwodofu-

1 Dodajmy jeszcze, że inną funkcją zapisu katakana jest wyróżnianie wyrazów w tekście, analogicznie do polskiego zapisu kursywą w tekście drukowanym.

${ }^{2}$ Dzisiaj niewielu Japończyków wie, że funkcjonowała też przez jakiś czas w polszczyźnie także ta druga, ortograficznie spolonizowana postać. Ciekawostką może być fakt, że w Warszawie nazwa ulicy jego imienia zmieniona została w zapisie $z$ formy ulica Fryderyka Szopena na formę ulica Fryderyka Chopina dopiero w roku 2012. 
suka (スクウォドフスカ - co transliterować można jako sukuu dofusuka) została zaadaptowana zarówno fonetycznie, jak i grafemicznie do warunków systemu fonologicznego języka japońskiego. Przede wszystkim zwraca tu uwagę występowanie wielu samogłosek, wstawionych tam, gdzie w języku polskim występuja zbiegi spółgłosek. Ponieważ język japoński jest językiem o przewadze otwartych sylab, to niemożliwe jest tutaj oddanie takich połączeń jak -sk-, -kt- czy -ws-. Zatem po spółgłoskach $s$ i $k$ pojawia się tutaj epentetyczna, $z$ polskiego punktu widzenia, samogłoska $u$. W pozycji między spółgłoskami bezdźwięcznymi jest ona jednak wymawiana bezdźwięcznie, toteż przedstawionego tutaj zapisu Sukuwodofusuka nie należy wymawiać $z$ wszystkimi samogłoskami dźwięcznymi. Dźwięcznie może być tu wymówiona jedynie samogłoska $o$, natomiast druga w kolejności litera samogłoskowa w zbiegu dwóch samogłosek $u_{o}$ wymawiana jako [ $\left.{ }^{\mathrm{w}} \mathrm{o}\right], \mathrm{w}$ tym zapisie sygnalizuje dźwięk podobny do polskiego $u$ niezgłoskotwórczego, wymawiane jako $\left[\mathrm{k}^{\mathrm{u}} \mathrm{o}\right]$. Początkujący Polacy uczący się języka japońskiego na ogół wymawiają taki zapis katakana bądź też jego wersję zlatynizowaną w transkrypcji Hepburna w sposób dosłowny i przesadny, jako [sukuodofusuka] z sylabizowanymi jako dźwięczne wszystkimi samogłoskami wyrazu, podczas gdy w wymowie Japończyków słyszy się raczej [sk ${ }^{\mathrm{w}}$ odo $\phi^{\mathrm{w}}$ ska] z ubezdźwięcznioną samogłoska /u/ po / $\phi /$ oraz /s/.

Jak widać, adaptacja fonetyczna polskiego nazwiska Skłodowska w japońszczyźnie połączona jest $z$ adaptacja grafemiczna, która tutaj polega na zapisie literami sylabicznego pisma katakana, w którym nie występuja oddzielne znaki literowe samogłosek i spółgłosek, ale litery odpowiadajacce sylabom składającym się $z$ nagłosowej spółgłoski i wygłosowej samogłoski. Powodem częstego stosowania sylab typu -su-, -ku-, -fu- czy -tsuw oddawaniu polskich zbiegów spółgłosek bezdźwięcznych jest fakt, że samogłoska $u$ wymawiana jest - tak, jak to zauważyliśmy - bezdźwięcznie między spółgłoskami bezdźwięcznymi, a także, w wygłosie wyrazu, jeżeli pojawia się po spółgłosce bezdźwięcznej. W ten sposób taka epenteza samogłoskowa w nazwiskach typu Malinowski, Biernacki czy Mokrzyński, stosowana w zapisie katakana w postaci Marinofusuki マリノフスキ, Byerunatsuki ビェルナツキ czy Mokushiinsuki モクシインスキ, staje się faktycznie jedynie epenteza grafemiczna, niesłyszalna w wymowie rdzennych Japończyków, gdyż przybiera postać Marinofski, Biernatski i Mokshiinski.

$Z$ tego też powodu, w transkrypcji nazwisk polskich zakończonych na bezdźwięczna spółgłoskę sz bądź też zawierających w zbiegu spółgłoskowym tę właśnie spółgłoskę, pojawił się w transkrypcji katakana zwyczaj dodawanej zmniejszonej litery yu $\_$w pseudosylabicznej sekwencji shu シュ, po to, aby zasygnalizować brak samogłoski w wymowie bliższej postaci oryginalnej. Tak więc nazwiska i imiona polskie typu Czesław Miłosz (Chesuwafu Miwoshu チェスワフ・ミウォシュ) czy Grzegorz Krychowiak (Gujegoshu Kurihobiaku グジェゴシュ・クリホビアク) zapisywane sa za pomoca tego dwuznaku literowego, sygnalizującego spółgłoskowy charakter wygłosu imienia Grzegorz (Gujegoshu グジェゴシュ) 
czy nazwiska Miłosz (Miwoshu ミウォシュ). Obocznie spotyka się także pisownię typu Grzegorz Lato - Gujegoshi Ratō グジェゴシ・ラトー (z nietypowym nieco wydłużeniem końcowej samogłoski w nazwisku, być może pod wpływem języka angielskiego jako języka pośredniczącego), z końcowa sylaba shi, wprowadzająca tutaj epentetyczna samogłoskę $i$. Jednakże w sasiedztwie spółgłosek bezdźwięcznych również samogłoska $i$ ulega $\mathrm{w}$ wymowie japońskiej ubezdźwięcznieniu i w związku $z$ tym tego rodzaju wstawka samogłoskowa, na podłożu czysto grafemicznym, jest praktycznie niesłyszalna. Tak więc, zarówno postać Gujegoshu グジェゴシュ jak i postać Gujegoshi グジェゴシ oddaje tutaj spółgłoskowy charakter wygłosu i w wymowie Japończyków jest bliższa oryginalnej postaci polskiej niż może się to wydawać na podstawie samego tylko zapisu katakana.

Dodajmy jeszcze, że inne polskie nazwisko osoby powiazanej rodzinnie $z$ Czesławem Miłoszem, a mianowicie poety Oskara Miłosza, który żyjąc na emigracji w Paryżu, zadeklarował wole przyjęcia obywatelstwa litewskiego, zostało upowszechnione w publikacjach w postaci zromanizowanej Oscar Milosz i do języka japońskiego trafiło pod jej wpływem w zapisie katakana jako Osukaru Miroshu オスカル・ミロシュz uwagi na brak spółgłoski /1/ w japońszczyźnie.

Trzeba jeszcze zauważyć, że w ogóle litery sylabiczne oddające w wymowie wygłosową samogłoskę $u$, nawet jeżeli nagłosowa spółgłoska ma charakter dźwięczny, służą powszechnie do sygnalizowania pojedynczych spółgłosek, a więc takie polskie nazwiska jak Anna Jantar czy Konrad Tom sa zapisywane w katakanie jako Anna Yantaru アンナ・ヤンタル i Konraddo Tomu コンラッド・トム. Osobna kwestię stanowi tutaj wykorzystywanie geminacji grafemicznej do odnotowywania pojedynczych spółgłosek dźwięcznych bądź bezdźwięcznych. Zilustrujemy to na przykładzie nazwiska innego sławnego Polaka, a mianowicie największego polskiego poety doby romantyzmu.

Nazwisko Adam Mickiewicz w zapisie katakana występuje w postaci Adamu Mitsukyevichi アダム・ミツキェヴィチ. W zapisie imienia poety pojawia się epenteza samogłoski $u$ wskutek zapisu sylabiczną litera $m u$ ム wygłosowej spółgłoski polskiej postaci imienia. Jeśli chodzi o wygłosową spółgłoskę $c z$ w nazwisku Mickiewicz, to w tej wersji występuje tu również czysto grafemiczna epenteza samogłoski $i$ w sylabicznej literze chi 千. Jednak wskutek ubezdźwięczniania tej samogłoski po spółgłoskach bezdźwięcznych w wymowie Japończyków jest ona praktycznie niesłyszalna.

Nazwisko Mickiewicza stało się bliższe Japończykom dopiero po japońskiej premierze filmu Andrzeja Wajdy Pan Tadeusz. Trudno zreszta przesądzić, czy postać poety jako autora dzieła, na którym oparty został film, jest tak znana nam, Japończykom, jak reżyser filmu. Zapewne odpowiedź brzmiałaby: nie. Niemniej jednak wielu czytelników, zainteresowanych kultura polska i polskim filmem oraz literaturami narodów słowiańskich, jest dzisiaj w stanie skojarzyć osobę, epokę oraz tradycję romantyzmu polskiego poprzez skojarzenie reżysera i filmu. 
Dla potrzeb prezentowanej tu analizy przywołamy niżej dwa fragmenty poematu Pan Tadeusz, przełożonego na japoński właśnie w powiazaniu $z$ premiera filmu A. Wajdy w Japonii, przez wybitnego tłumacza literatury polskiej - Yukio Kudō - i wydanego w popularnej, kieszonkowej serii literatury światowej - Kōdansha Bunko. We fragmentach tych pojawiają się licznie przywołane przez poetę nazwiska polskie, których zaadaptowana do japońszczyzny fonetycznie postać w przekładzie może zainteresować polskich czytelników. Będa to dwa fragmenty $z$ pierwszej księgi Pana Tadeusza, które podamy w wersji oryginalnej, wraz z przekładem japońskim i jego transliteracją łacińska w systemie Hepburna. Oto pierwszy fragment [s. 73 i 74]:

Mō hanji wa nemutte ita. Teiri wa sotto kan no genkan no aida e

もう判事は眠っていた。廷吏はそっと館の玄関の間へ

Już sędzia spał. Więc woźny cicho wszedł do sieni.

Rōsoku no soba ni koshikake, poketto kata kogata nōto o hikidashita 蠟燭の側に腰掛け、ポケットから小型ノートを引き出した

Siadł przy świecy i dobył książeczkę z kieszeni,

Kore wa kitōsho nami ni hadami hanasazu mochiaruki

これは祈禱書なみに肌身はなさず持ち步き

Która mu jak Ołtarzyk Złoty zawsze służy,

Ie ni ite mo tabi ni detemo tebanashita koto ga nai.

家にいても旅に出ても手放したことがない。

Której nigdy nie rzuca w domu i w podróży.

Saibansho no shōkanjō no kiroku de, soko ni wa zurari to

裁判所の召喚状の記録で、そこにはずらりと

Była to trybunalska wokanda: tam rzędem

Soshō jikō ga kinyū sare, saibansho no teiri to shite

訴訟事項が記入され、裁判所の廷吏として

Stały spisane sprawy, które przed urzędem

Kare ga sono mukashi, jibun no koe de yobidashita na mo areba

彼がその昔、自分の声で呼び出した名もあれば

Woźny sam głosem swoim przed laty wywołał,

Nochi ni natte kono hito ka to wakatta namae mo narande ita.

のちになってこの人かと分かった名前も恶んでいた。

Albo o których późniéj dowiedzieć się zdołał.

Mongaikan wa hon no seimei no raretsu to omoeru no da ga

門外漢にはほんの姓名の羅列と思えるのだが

Prostym ludziom wokanda zda się imion spisem;

Teiri ni totte wa rippa na fūbō no sugata ga omoidasareru

廷吏にとっては立派な風貌の姿が思い出される

Woźnemu jest obrazów wspaniałych zarysem. 
Dakara yominagara omoi ni fuketta. Oginsuki tai Vizugirudo だから読みながら思いに耽った。オギンスキ対ヴィズギルド

Czytał więc i rozmyślał: Ogiński $z$ Wazgirdem,

Dominiko-Kai tai Ruimusha, Ruimusha tai Vizugirudo

*ドミニコ会対ルィムシャ、ルィムシャ対ヴィズギルド

Dominikanie $z$ Rymsza, Rymsza $z$ Wysogirdem,

Rajiviu tai Vereshichaka, Giedoroichi tai Roduutofusuki

ラヂヴィウ対ヴェレシチャカ、ギエドロイチ対ロドゥウトフスキ

Radziwiłł z Wereszczaka, Giedrojcie z Rdułtowskimi,

Obuhovichi tai Yudaya jichikai, Yurāha tai Pyotorofusuki

オブホヴィチ対ユダヤ自治会、ユラー八対ピョトロフスキ

Obuchowicz z Kahałem, Juraha z Piotrowskim,

Maresuki tai Mitsukievichi, matsubi ni wa hakushaku ni tai suru ni

*マレスキ対ミツキエヴィチ、末尾には伯爵に対するに

Malewski z Mickiewiczem, a na koniec Hrabia

Sopuritsa. Yonde yuku uchi, namae no naka kara

ソプリツァ。読んでゆくうち、名前のなかから

$Z$ Soplica; i czytając, $z$ tych imion wywabia

Shinri no daironten, samazama na dekigoto no kioku ga ukabi

審理の大論点、さまざまな出来事の記憶が浮かび

Pamięć spraw wielkich, wszystkie procesu wypadki,

Me no mae ni hōtei ya arasou sōhō ya shōnin-tachi ga tachinarabu.

目の前に法廷や争う双方や証人たちが立ち並ぶ。

I stają mu przed oczy sąd, strony i świadki;

Shiro no jupan o kite, ue ni kon no kontushu o haori

白のジュパンを着て、上に紺のコントゥシュを羽織り

I ogląda sam siebie, jak w żupanie białym,

Saibankan no seki ni muite tatsu jibun no sugata made miete kuru.

裁判官の席に向いて立つ自分の姿まで見えてくる。

W granatowym kontuszu stał przed trybunałem,

Katate de sāberu o osae, katate o taku ni oki

片手でサーベルを抑え、片手を卓に置き

Jedna ręka na szabli, a druga do stoła;

Yobidashita sōhō ni „Seishuku ni!! to gōrei suru.

呼び出した双方に「静肃に!」と号令する。

Przywoławszy dwie strony: „Uciszcie się!” woła.

Musō shinagara, dōji ni yūbe no inori o tonaeoete

夢想しながら、同時に夕べの祈りを唱え終えて

Marząc i kończąc pacierz wieczorny, pomału

Litova saigo no teiri wa sugu ni neitta.

リトヴァ最後の廷吏はすぐに寝入った。

Usnął ostatni w Litwie Woźny trybunału. 
We fragmencie tym pojawia się szereg nazwisk polskiej szlachty $z$ rodzinnych stron A. Mickiewicza. Nazwiska te nosili adwersarze w procesach sądowych, które przypomina sobie sędzia. Są to zatem takie nazwiska, jak:

- Ogiński-Oginsuki オギンスキ-w japońskim zapisie katakana zanika miękkość spółgłoski [N]. Dzisiaj w niektórych zapisach sygnalizuje się tę miękkość poprzez dodanie litery $i$ przed szczelinowa spółgłoską $[\mathrm{N}]$,

- Wazgird-Vizugirudo ヴィズギルド - zapewne przez niedopatrzenie zostało błędnie zapisane w katakanie $\mathrm{z}$ epentetycznie wstawionymi samogłoskami $u$ oraz o wskutek zapisu literami sylabicznymi rudo ルド; $\mathrm{w}$ nazwisku tym, podobnie jak w wielu nazwiskach omawianych niżej, pojawia się też specjalna litera katakany, stosowana do oddawania dźwięcznej spółgłoski wargowo-zębowej $w$ [v], a mianowicie ヴ,

- Rymsza-Ruimushaルィムシャ - w nazwisku tym polska samogłoska y oddawana jest przez dyftong ui w dwuznaku literowym rui ル ,

- Wysogird - zapewne wskutek błędu drukarskiego nazwisko to zostało powtórzone $z$ poprzedniego wersu, zapisane jako Vizugirudo ヴィズギルド,

- Radziwitt - Rajiviuラヂヴィウ - ma postać nieodbiegającą od postaci polskiej, podobnie jak nazwisko Wereszczaka-Vereshichaka ヴェレシ チャカ - w którym ekwiwalentami polskich spółgłosek twardych sz [J] i $c z$ [t] sa japońskie spółgłoski miękkie shi [6] i chi [t6], z powodu braku twardych spółgłosek szczelinowych i zwartych w języku japońskim,

- Giedrojć - jako Giedoroichi ギエドロイチ - występuje tu wyłącznie epenteza samogłoskowa wskutek zapisu sylabicznego podobnie jak Rduttowski-Roduutofusuki ロドゥウトフスキ,

- Obuchowicz-Obuhovichi オブホヴィチ - pojawia się sylaba wi [vi] zapisana ヴィ,

- Juraha - Yurāha ユラーハ - pojawia się wzdłużenie środkowej samogłoski $a$-zapewne w celu zasygnalizowania miejsca akcentu,

- Piotrowski-Pyotorofusuki ピョトロフスキ-pojawiaja się tu w zapisie liczne epentezy samogłoskowe, ale maja one charakter czysto grafemiczny i w faktycznej wymowie japońskiej polskie zbiegi spółgłoskowe realizowane sa jak gdyby pośrednio między fonetycznym standardem polskim a japońskim,

- Malewski - Maresuki マレスキ - nazwisko to zostało zapisane $\mathrm{w}$ postaci uproszczonej (opuszczono tutaj głoskę $w$ wymawiana jako [f]), podobnie jak wymawiaja je dzisiaj Polacy. 
Również główne dla treści utworu nazwisko Soplica zaadaptowane zostało w japońszczyźnie w nieco zmienionym kształcie jako Sopuritsa ソプリツァ z powodu fonetycznej rozbieżności japońszczyzny i polszczyzny. $Z$ punktu widzenia języka japońskiego nietypowym zapisem jest tutaj sylaba tsa ツァ, będąca połączeniem sylabicznych liter tsu ツ oraz małego $a$ s.

Również w następnym fragmencie pojawiają się liczne nazwiska [s. 76-77]:

Rōjin no hanashigatari wa hisoka ni murajū ni tsutawatta.

老人の話がたりは密かに村じゅうに伝わった。

Mowy starca krażyły we wsi po kryjomu;

To aru shōnen wa hanashi o kiite kara totsuzen ni iede o shite

とある少年は話を聞いてからとつぜんに家出をして

Chłopiec, co je posłyszał, znikał nagle $z$ domu,

Mori o nuke numachi o watari, yukue fumei no shissōchū ni

森を抜け沼地を渡り、行方不明の失踪中に

Lasami i bagnami skradał się tajemnie,

Mosukāre ni owarete tobikomi, Niemen-gawa ni kakure

モスカーレに追われて飛び込み、二エメン川に隠れ

Ścigany od Moskali, skakał kryć się w Niemnie,

Mogutte soko o oyogikiri, Warushawa Kōkoku gawa no kishi ni tsuita totan

潜ってそこを泳ぎ切り、ワルシャワ公国側の岸に着いたとたん

I nurkiem płynął na brzeg księstwa Warszawskiego,

Ureshii koe ga mimi ni haitta — „Yoku kita na, senyū!” to.

嬉しい声が耳に入った一「よくきたな、戦友!」と。

Gdzie usłyszał głos miły: „Witaj nam kolego!”

Daga, soko o saru mae ni, iwa no ōi koyama ni nobori, Niemen no

だが、そこを去るまえに、岩の多い小山に登り、二エメンの

Lecz nim odszedł, wyskoczył na wzgórek $z$ kamienia,

Kawagoshi ni Mosukāre e aisatsu shita — „Mata aō ze!”

川越しにモスカーレへ挨拶した一「また会おうぜ!」

I Moskalom przez Niemen rzekł: „Do zobaczenia!”

Kō shite dasshutsu shita no wa Guretsuki, Pattsu, Obuhovichi

こうして脱出したのは*グレッキ、パッツ、オブホヴィチ

Tak przekradł się Górecki, Pac i Obuchowicz,

Pyotorofusuki, Oborefusuki, Rojitsuki, Yanovichi

ピョトロフスキ、オボレフスキ、ロジツキ、ヤノヴィチ

Piotrowski, Obolewski, Rożycki, Janowicz

Mijeiefusuki kyōdai, Burohotsuki, Berunatovichi kyōdai

ミジェイエフスキ兄弟、ブロホツキ、ベルナトヴィチ兄弟

Mierzejewscy, Brochocki i Bernatowicze, 
Kupushichi, Gedimin sono ta, ato wa ryaku su.

クブシチ、ゲディミン その他、あとは略す。

Kupść, Gedymin i inni, których nie policzę:

Karera wa minna ryōshin o sute, ai suru tochi o ato ni shi

彼らはみんな両親を呆て、愛する土地をあとにし

Opuszczali rodziców i ziemię kochana,

Sono zaisan wa Roshia teikoku no kokko ni meshiagerareta.

その財産は*ロシア皇帝の国庫に召し上げられた。

I dobra, które na skarb Carski zabierano.

Nazwiska te stanowią dla czytelnika japońskiego podwójną trudność, gdyż nie tylko znaczna obcość brzmienia utrudnia ich percepcję, ale również samo ich nagromadzenie w takiej liczbie. Przeciętny czytelnik japoński, nieobeznany $z$ realiami polskimi, skazany jest tutaj na mozolne sylabizowanie ich postaci dźwiękowej, paradoksalnie w dosłownym rozumieniu tego terminu, gdyż każda sylaba musi tutaj być składana odrębnie w długą całość. W dodatku fonotaktycznie są to rządki całkowicie odrębne od japońskich reguł sąsiedztwa sylabicznego. Można zakładać, że żaden czytelnik japoński nie jest w stanie nie tylko odróżniać, ale nawet zapamiętać wszystkich tych sekwencji.

W wypadku mnogiej formy Mierzejewscy oraz Bernatowicze, zaadaptowanej w postaci ミジェイエフスキ兄弟 oraz ベルナトヴィチ兄弟, thumacz zastosował polska formę liczby pojedynczej z dodatkiem generycznego ekwiwalentu kyōdai 兄弟 'bracia', wnoszącego znaczenie mnogości oraz informacji o tym, że chodzi tutaj o braci, czyli spokrewnionych ze soba mężczyzn.

W nazwisku Pac, dla zasygnalizowania oryginalnego wygłosu spółgłoskowego postaci polskiej, zastosowana została geminacja do postaci Pattsu パッツ. Techniki tej tłumacz nie zdecydował sie jednak zastosować do zapisu nazwiska Obuchowicz (Obuhovichi オブホヴィチ) czy Janowicz (Yanovichi ヤノヴィチ), być może ze względu na to, że naturalnie przejawiające się $\mathrm{w}$ języku japońskim ubezdźwięcznianie samogłoski [i] w wygłosie (po spółgłosce bezdźwięcznej) może być traktowane jako częściowy ekwiwalent, odzwierciedlający sylabiczne właściwości polszczyzny i częste występowanie w niej sylab zamkniętych.

Bardzo wyrazistym przykładem takiej zachowanej ekwiwalencji między polszczyzna a japońszczyzną może być nazwisko Kupść, oddane w transkrypcji japońskiej za pomoca katakany w postaci Kupushichi クプシチ. Należy jednak ponownie przywołać tu nieznane w polszczyźnie zjawisko ubezdźwięczniania samogłosek [i] oraz [u] także w śródgłosie, w pozycji między spółgłoskami bezdźwięcznymi. W ten sposób Japończycy wymawiaja to nie jako [kupucitci] (czyli tak, jak to sylabizuja polscy czytelnicy transkrypcji Hepburna), ale jako [kupstci], z jedyna samogłoską dźwięczną na początku tej sekwencji oraz z pozostałymi samogłoskami ubezdźwięcznionymi. 
Wrócimy teraz do kwestii japońskiej postaci nazwiska Lecha Wałęsy. Forma Waresa ["Waresa] ワレサ jest japońska wymowa zapisu Walesa, upowszechnianego w prasie angielskojęzycznej i pozbawionego polskich znaków diakrytycznych w literach alfabetu lacińskiego. Pierwsza sylaba nazwiska jest po angielsku wymawiana tak samo jak po japońsku, a więc jako [" ${ }^{\mathrm{w}}$ ]. Wyłącznie japońska adaptacja fonetyczna polegała tutaj na charakterystycznej zmianie, jaka jest pojawienie się $r \mathrm{w}$ miejsce angielskiego $l$, a pierwotnie polskiego $t$.

W standardowym języku japońskim, jak już zostało to wspomniane wcześniej, nie występuje głoska $l$, w związku z tym brakuje tu pary opozycyjnej $r: l$, a w zapożyczeniach obcojęzycznych głoska $l$ zastępowana jest przez głoskę $r$. Widzimy więc, że polska głoska $z$ [u] została tutaj sztucznie - na płaszczyźnie czysto grafemicznej - zastapiona w angielskim zapisie przez głoskę $l$ i dopiero na gruncie języka japońskiego pojawiła się tutaj głoska $r$. Jest rzeczą charakterystyczna, że polska głoska $ł$ bywa też zapożyczana do języka japońskiego - bez takiego pośrednictwa zapisu obcojęzycznego - w zróżnicowany sposób. Przed samogłoska $u \mathrm{w}$ polskiej sylabie $\underline{\underline{u} u}$ adaptacja japońska prowadzi do zaniku spółgłoski i w zwiazku $z$ tym nazwisko polskiego logika oraz filozofa Jana Łukasiewicza przybiera postać Yan Ukashevichi ヤン・ウカシェヴィチ. Natomiast przed samogłoską e spółgłoska $k \mathrm{w}$ wymowie japońskiej otrzymuje ekwiwalent [ $\left.{ }^{\mathrm{w}} \mathrm{e}\right] \mathrm{i}$ taką postać można zaobserwować w stosowanej od pewnego czasu korekcie nazwiska Lecha Wałęsy, a mianowicie Refu Vauensa レフ・ヴァウェンサ.

W korekcie tej, upowszechnianej w wydawnictwach encyklopedycznych i opracowaniach biograficznych, ale nadal nierozpowszechnionej w środkach masowego przekazu i w obiegu potocznym, zauważamy trzy innowacje.

Przede wszystkim wprowadzony został ekwiwalent polskiej spółgłoski $w$ - o postaci obcej japońszczyźnie - choć od pewnego czasu stosowanej w odniesieniu do zapożyczeń $z$ języków obcych jako spółgłoska szczelinowa, wargowo-językowa $v[\beta]$, zapisywana specjalnie do tego stworzonym znakiem literowym w katakanie - ヴ (znak literowy u ウ $z$ dodatkiem diakrytycznego oznaczenia dźwięczności zwanego nigori, który tutaj sygnalizuje spółgłoskowy charakter dźwięku). Trzecią innowacja jest tutaj wprowadzenie ekwiwalentu polskiej samogłoski nosowej $e \mathrm{w}$ postaci dyftongu en. Korekta ta wymagała zreszta istotnych modyfikacji zapisu w katakanie poprzez zastosowanie dwuznaków literowych va ヴァ oraz ue ウェ, ze zmniejszonymi znakami samogłoskowymi, aby można było $z$ liter ヴ [ $[\beta u]$ oraz ウ [u] wykorzystać jedynie ich fonetyczną wartość nagłosowa o funkcji spółgłoski. Dodatkowo jeszcze w imieniu Lech, zaadaptowanym do japońskiego w postaci Refu, zauważamy objaśniona wyżej ekwiwalencje spółgłoski $l$ zastapionej przez $r$ i ekwiwalencję spółgłoski $h$ zastapionej przez typową dla języka japońskiego dwuwargową spółgłoskę $f$, występującą wyłącznie przed samogłoską $u$, która jest tutaj w wygłosie ubezdźwięczniana do postaci ref [r e $\phi]$. 
Trudno dziś przewidywać, czy ta skorygowana wersja nazwiska $W a-$ łęsa zdoła się upowszechnić szerzej, gdyż zwyczaj językowy oddziałuje tu silnie i nadal wszystkie niemal media przywołuja postać tradycyjna $\mathrm{Wa}$ resa, traktowana jako standardowa. Co więcej, nawet w tytule japońskim biograficznego filmu Andrzeja Wajdy Wałęsa. Człowiek z nadziei pojawia się standardowa postać: Waresa - Rentai no otoko ワレサ 連带の男, dosł. Wałęsa-człowiek Solidarności.

\title{
Bibliografia
}

R. Huszcza, M. Ikushima, J. Majewski, 1998, Gramatyka japońska, t. I, Kraków. A. Mickiewicz, 2018, Pan Tadeusz, czyli ostatni zajazd na Litwie, Wrocław. (przekład japoński autorstwa Kudō Yukio, 1999, Pan Tedeushu (część I oraz II), Tōkyō).

K. Satō, 1996, Kanji hyakka daijiten, Tōkyō.

K. Shōichi et al., 1981, Mały słownik polsko-japoński, Tōkyō.

\section{Phonetic and graphemic adaptations of Polish first and last names in the contemporary Japanese language}

\author{
Summary
}

While summarising the observations about the phonetic and graphemic adaptations of Polish last and first names in the Japanese language, one can notice that the source form and the target form of such an adaptation differ from each other to a large extent. The main cause of this situation is the discrepancy between the phonological systems of both languages. In simple terms, many Polish consonants do not have equivalents in Japanese and must be rendered using substitute equivalents. Another issue here is the principal foreignness of Polish last names to an average Japanese language user. They are long, do not resemble any patterns of more universal last or first names, since words of this kind are always connected with their native language, culture, and tradition.

Keywords: translation - phonetic adaptation - graphemic adaptation - last name - first name - Polish language - Japanese language

Trans. Monika Czarnecka 